Arab Univ. J. Agric. Sci., Ain Shams Univ., Cairo, Egypt

27(3), 1829-1841, 2019

Website: http://ajs.journals.ekb.eg

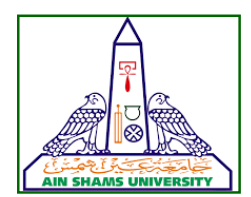

1829

\title{
ENHANCEMENT OF RESISTANCE AGAINST RHIZOCTONIA SOLANI BY GLYCINE BETAINE AND UV-C RADIATION IN GREEN BEAN (Phaseolus vulgaris L.)
}

\author{
Aboul Fotouh ${ }^{1^{*}}$ M.M., Maha H. Mohamed ${ }^{2}$, Moawad ${ }^{1}$ F.G., \\ Tag El-Din ${ }^{1}$ M.A. and Srour ${ }^{1}$ H.A.M. \\ 1- Agric. Biochemistry Dept., Fac. of Agric., Ain Shams Univ., P.O. Box 68, Hadayek Shubra \\ 11241, Cairo, Egypt \\ 2- Plant Pathology Dept., Fac. of Agric., Ain Shams Univ., P.O. Box 68, Hadayek Shubra 11241, \\ Cairo, Egypt \\ *Corresponding author: mohamed mesalhi@agr.asu.edu.eg
}

Received 24 July, 2019

Accepted 18 September, 2019

\section{ABSTRACT}

Rhizoctonia solani is considered one of the most harmful pathogens affecting green bean productivity. Phaseolus vulgaris, L. cv. paulista seeds were subjected to UV-C for $60 \mathrm{~min}$. and/or immersed in glycine betaine (GB, $5 \mathrm{mM}$ ) for 24 hours to stimulate plant biochemical defenses against $R$. solani. After treatments, seeds were sown in soil infested with $R$. solani, then seedling samples were collected after two weeks to evaluate plant resistance and some antioxidant enzymes activities. The results clearly demonstrated that disease index (DI) was highly reduced by GB (54.7\%) followed by UV+GB (38.3\%) and UV (35.6\%). Seed treatment with UV-C for 60 min or $\mathrm{GB}(5 \mathrm{mM})$ for $24 \mathrm{~h}$ alone or together enhanced plant rooting in infected seedlings comparing with control. Also, there was a high correlation between the levels of lipid peroxidation and Rhizoctonia root rot disease index. Seed treated with UV-C, GB or both mitigated the effect of infection on the lipid peroxidation (Malondialdehyde levels) with percentages of $26.8,40.2$ and $29.3 \%$ respectively in comparison with the infected control. Regarding to the plant defensive enzymes, GB was the only treatment that triggered a significant increment in the superoxide dismutase (SOD) activity in roots of both infected and non-infected seedlings as compared to the control. On the other hand, guaiacol peroxidase (G-POD) and polyphenol oxidase (PPO) activities were elevated by all treatments in infected plant roots in comparison with control. The maximum activity for G-POD was attained with UV treatment (9042.5 U.mg-1 protein) followed by
GB+UV, GB and infected control with values of 7776.5, 7152.4 and 6508.8 U. $\mathrm{mg}^{-1}$ protein, respectively. Similarly, PPO exhibited higher activities with significant differences in all treatments over the infected control with percentages of $54,59.4$ and $48.7 \%$ for UV, GB and UV+GB respectively. Finally, it can be concluded that treatment of green bean seeds with UV-C and GB enhanced green bean seedlings tolerance to $R$. solani by activation of the antioxidant enzymes and activation of defense-related enzymes like polyphenol oxidase. The results of combination of UV-C and GB treatments indicated the absence of synergetic effects in induction of plant tolerance.

Keywords: Rhizoctonia solani, Green bean, Glycine betaine, UV, Seed treatment, Induced resistance

\section{INTRODUCTION}

Common bean (Phaseolus vulgaris L.) is considered one of the most important legumes worldwide. It is well known that common bean seeds are important sources for proteins, minerals and diabetic fibers (De La Fuente et al 2011). However, the productivity of this crop is seriously affected by infection with various pathogens. For instance, it is reported that about $16 \%$ losses due to plant diseases and $10 \%$ losses are attributed to seed-borne diseases (Fakir, 1983).

Rhizoctonia solani Kükn [Teleomorph: Thanatephorus cucumeris (Frank) Donk] is one of the pathogens that can be transmitted by seeds or soil (Sivalingam et al 2006; Hajieghrari et al 2008) 
and is also known as a soil-borne fungal pathogen responsible for root rots and seedlings damping off in common bean and other crops (El-Mougy et al 2007). Many synthetic fungicides like metalaxyl-M, propamocarb hydrochloride and azoxystrobin are recently used to control the disease despite their adverse consequences on human health and environment (Arcury and Quandt, 2003). Accordingly, many research efforts were exerted to develop harmless and efficient alternative means for synthetic pesticides such as biological control or via induction of defense responses in healthy plants (Mayo et al 2015; Abdel-Fattah et al 2011).

Seed priming is a cost-effective pre-sowing technique for enhancing plant tolerance to various stresses. In seed priming techniques, seeds are usually exposed to limited hydration by using osmolytes e.g. polyamines and sugar alcohols in order to stimulate pre-germinative metabolic processes via proteins synthesis and up regulate many genes responsible for plant tolerance against biotic and abiotic stresses (Paul and Roychoudhury, 2017; Kaur et al 2002). Priming also involved seed treatment with plant growth regulators like salicylic acid (Basra et al 2007) or bioagents such as fluorescent Pseudomonas, Trichoderma harzianum and Glomus intraradices (Srivastava et al 2010). Many studies evaluated some plant extracts such as moringa leaf extract (Rady et al 2013) as a priming agent which enhanced the plant growth under salinity stress. As well, UV-C radiation stimulated the adaptive mechanisms to salinity stress in green bean seedlings (Aboul Fotouh et al 2014). The common purpose of seed priming is to speed up the rate of plant response to both biotic and abiotic stresses during and after germination. Induction of resistance by seed priming is like building a stress memory in plants and is correlated with chromatin modifications, transcription factors, posttranslational modifications, phytohormones, and metabolites involved in stress management (Conrath, 2011).

Glycine betaine (GB, N,N,N-trimethyl glycine) is a naturally occurring amino acid derivative in plants and other organisms. It was suggested by Zhang et al (2017) that it has a protective role for proteins and other high-order molecules in the cell providing a high potential role in stress tolerance. Many studies elucidated the effect of exogenous application on the acquisition of tolerance against several abiotic stresses. For example, foliar application of GB at $25 \mathrm{mM}$ mitigated the negative effects of saline stress in lettuce and elevated the activities of superoxide dismutase, catalase, perox- idase and ascorbate peroxidase (Shams et al 2016). Nevertheless, the efficacy of GB was little considered with biotic stress except for few studies. For instance, Lavanya and Amruthesh (2017) reported that GB was effective for the control of downy mildew disease in pearl millet.

UV seed priming has been proven to be a promising approach to control diseases. According to Scott et al (2019), treatment of seeds with UV-C radiation had a positive impact on reduction of disease incidence in tomato by Botrytis cinerea and Fusarium oxysporum f. sp. lycopersici. Also, Brown et al (2001) reported that exposure of cabbage seeds to hormetic dose $\left(3.6 \mathrm{KJ} . \mathrm{m}^{-2}\right)$ of UV-C reduced the population density of Xanthomonas campestris pv. campestris in infected leaves.

The objective of this study was to evaluate the efficacy of common bean (Phaseolus vulgaris, $\mathrm{L}$. Cv. paulista) seed priming with glycine betaine and exposure to low dose of UV-C radiation individually or in combination on resistance to the necrotrophic fungus $R$. solani. Moreover, the study aimed to shed light on the biochemical changes associated with induction of resistance against $R$. solani in green bean seedlings.

\section{MATERIALS AND METHODS}

\section{Plant material}

Common bean seeds (Phaseolus vulgaris, L. cv. paulista) were obtained from the Central Administration for Seed Certification, Ministry of Agriculture and Land Reclamation, Dokki, Egypt.

\section{Pathogen isolation and preparation of inocu- lum}

Rhizoctonia solani Kühn [Teleomorph: Thanatephorus cucumeris (Frank) Donk] was isolated from faba bean plants that exhibited symptoms of root rot disease. The isolate which was identified as $R$. solani AG4-HGl by Mohamed et al (2015a) was used for infection of common bean seedlings.

\section{Preparation of fungal inoculum and soil infesta- tion}

Dried sandy clay soil (1:1) was obtained from greenhouse of plant pathology department and placed in petri dishes $(9 \mathrm{~cm}$ diameter) by rate of $100 \mathrm{~g} /$ plate, then wetted by Czapek Dox broth (25 $\mathrm{ml} /$ plate). Dishes were autoclaved at $121^{\circ} \mathrm{C}$ for 30 min. After cooling, dishes were infested by pieces 
of actively $R$. solani growth. Then, plates were incubated in the dark (at $25 \pm 1^{\circ} \mathrm{C}$ ) for 10 days. Dishes with sandy clay soil contained fungal growth were used for infestation of pots $(10 \mathrm{~cm}$ in diameter). Each pot contained approximately $400 \mathrm{~g}$ autoclaved sandy clay soil. Each pot received one dish containing the inoculum source.

\section{Seed Treatments}

Common bean seeds were firstly sterilized using sodium hypochlorite (2\%), then washed by sterilized distilled water. Seeds were divided into two groups: the first one was treated with sterilized distilled water and the other was treated with glycine betaine (GB, $5 \mathrm{mM}$ ). Both groups of seeds were placed between two layers of paper towels, then water or GB solution was added to cover all the seeds. The treatments lasted for $24 \mathrm{~h}$ at $28^{\circ} \mathrm{C}$. Afterwards, treated seeds were washed by sterilized distilled water and germinated in petri dishes. After 2 days, both groups were divided into two subgroups: the first one was left without further treatment, while the other was exposed to UV-C radiation $(254 \mathrm{~nm})$ from an artificial source (lamp TUV 15W G158T8 UV-C long life, Holland Philips special) which was situated at $20 \mathrm{~cm}$ over the seeds. After $60 \mathrm{~min}$, UV-treated seeds were stored in complete darkness for $24 \mathrm{~h}$ to minimize any photoreaction processes. Subsequently, germinated seeds were used for pot experiment.

\section{Greenhouse experiment}

The experiment was conducted in the greenhouse of Plant Pathology Department, Faculty of Agriculture, Ain Shams University. The four groups of previously treated seeds were randomly distributed into two subgroups: the first one was sown in non-infested soil, while the other was placed in infested soil. Therefore, the final design of the experiment had eight treatment sets with 10 replicates in each one as following: (1) Control (hydroprimed seeds without infection), (2) Infected control (hydro-primed seeds with infection), (3) UV-treated seeds in non-infested soil, (4) UV-treated seeds in infested soil, (5) Glycine betaine (GB, $5 \mathrm{mM}$ )treated seeds without infection, (6) GB-treated seeds with infection, (7) GB+UV (non-infected), (8) $\mathrm{GB}+\mathrm{UV}$ (infected). After two weeks of regular irrigation, plant roots were collected and washed for evaluation of disease index, then stored at $-22^{\circ} \mathrm{C}$ for biochemical analysis.

\section{Determination of disease index}

The disease index was determined according to the method of Abawi et al. (2006) with some modifications by Mohamed et al. (2015b).

\section{Biochemical analysis}

\section{Determination of lipid peroxidation}

In order to determine the level of lipid peroxidation in roots, the method described by Heath and Packer (1968) was followed. Lipid peroxidation was expressed as nmol MDA. $\mathrm{g}^{-1} \mathrm{FW}$.

\section{Enzyme assays}

Root tissues $(0.5 \mathrm{~g})$ were pulverized in $100 \mathrm{mM}$ chilled sodium phosphate buffer $(\mathrm{pH} 7)$ containing $1 \%(\mathrm{w} / \mathrm{v})$ polyvinylpyrrolidone (PVP) and $0.1 \mathrm{mM}$ EDTA. Four $\mathrm{ml}$ extraction buffer were used for each one gram of plant tissues. The homogenate was centrifuged at $6000 \mathrm{rpm}$ at $4^{\circ} \mathrm{C}$ for $15 \mathrm{~min}$. The supernatant was used for measuring guaiacol peroxidase (G-POD), polyphenol oxidase (PPO) and superoxide dismutase (SOD) activities.

Superoxide dismutase (SOD) (EC 1.15.1.1) activity was measured based on the method of Beyer and Fridovich (1987). The enzyme activity was expressed as unit.mg ${ }^{-1}$ protein.

Guaiacol peroxidase (EC 1.11.1.7) activity was determined by the method of Hammerschmidt et al (1982). The G-POD activity was expressed as unit. $\mathrm{mg}^{-1}$ protein.

Polyphenol oxidase (PPO) (EC 1.14.18.1) activity was measured according to Oktay et al (1995). The enzyme activity was expressed as unit. $\mathrm{mg}^{-1}$ protein.

Protein concentration was quantified according to Bradford (1976) using bovine serum albumin for the standard curve.

\section{Statistical analysis}

The analyses were performed in triplicate. All data are presented as means $\pm S D$. The results were analyzed by one-way ANOVA using Costat software (Version 6.303) according to Stern (1991). The significance of difference between treatments was tested by Duncan's multiple range test at $\mathrm{P} \leq 0.05$. 


\section{RESULTS AND DISCUSSION}

\section{Disease index}

Data in Fig. (1) show that disease index (DI) was significantly reduced by $35.6,38.3$ and $54.7 \%$ in plants grown from seeds treated with UV, $\mathrm{GB}+\mathrm{UV}$ and $\mathrm{GB}$, respectively compared with untreated control. Obviously, the symptoms of disease were extremely decreased on the roots of plants grown from GB-treated seeds (Fig. 2C). Also, Fig. (2) demonstrates that seed treatment with UV-C for $60 \mathrm{~min}, \mathrm{~GB}(5 \mathrm{mM})$ for $24 \mathrm{~h}$ or both enhanced plant rooting in infected seedlings as compared with control. Such effect should oppose the impact of infection by improving the efficiency of primed plants roots in absorption of water and nutrients which increased the survival of primed plants after infection with $R$. solani.

The induction of green bean resistance via UV$\mathrm{C}$ treatment was in agreement with results of $\mathbf{X u}$ et al (2019) who reported that repeated exposure of strawberry leaves to UV-C after inoculation by $M y$ cosphaerella fragariae, the causal agent of leaf spot disease, reduced the symptoms of disease with altered gene expression in leaves. The impact of UV-C implicated over production of volatile terpenes, phenolic compounds and pathogenesisrelated (PR) proteins, referring to the role of UV-C in eliciting plant defense responses (Xu et al 2019).

Regarding to the effect of GB on resistance to pathogens, similar results were also observed by Lavanya and Amruthesh (2017). They found that seed treatment with GB (30 mg. $\left.\mathrm{ml}^{-1}\right)$ reduced the disease incidence of downy mildew to $33 \%$ in pearl millet and the primed seedlings showed early expression of hypersensitive response (HR).

Upon infection, plants evolve defence mechanisms which involve: (i) stimulation of antioxidant system (Wang et al 2017), (ii) upregulation of antifungal compunds (phytoalexins) biosynthesis (Dixon, 2001), (iii) enhanced expression of pathogenesis-related (PR) proteins (Guerrero-González et al 2011). However, the rate of response differs between susciptible and resistant plants. In the present study, priming with UV-C for $60 \mathrm{~min}$ and/or GB (5 $\mathrm{mM}$ ) provided green bean seedlings with the ability to activate plant defenses against infection with $R$. solani more rapidly than control plants.

\section{Effect of treatments on lipid peroxidation}

Malondialdehyde (MDA) is one of biomarkers for oxidative damage (Farmer and Mueller, 2013). Fig. (3) shows that treatment with GB caused a significant increment in MDA concentration in roots of non infected common bean with a percentage of $57.8 \%$ higher than control plants. Infection with $R$. solani led to a marked increase in the levels of MDA as compared with control by $69.9 \%$. Seed priming with UV-C, GB or both mitigated the effect of infection on the lipid peroxidation (MDA) with values of $14.2,11.6$ and 13.7 nmol.g ${ }^{-1} \mathrm{FW}$ respectively in comparison with the infected control (19.4 nmol.g $\left.{ }^{-1} \mathrm{FW}\right)$. These results were consistent with the severity of disease symptoms on plants roots.

The appearance of necrotic lesions on infected plant roots resulted from the oxidative burst accompanying the infection with $R$. solani due to hyper generation of ROS. These observations agreed with the data obtained by Wang et al (2017). They noticed that the accumulation of $\mathrm{H}_{2} \mathrm{O}_{2}$ and $\mathrm{O}_{2}{ }^{-}$increased in Stylosanthes guianensis leaves infected by Colletotrichum gloeosporioides. Therefore, hyper generation of ROS without sufficient antioxidant system triggered cellular membranes damage and then lipid peroxidation (LP), leading to high concentrations of MDA, the secondary product of LP, in infected non-primed plants and with lesser extent in infected primed plants as it is shown in Fig. (3).

Oxidative stress tolerance has a significant role in controlling the plant disease (Youssef et al 2016). UV-C irradiation of bean seeds enhanced the antioxidant machinery in plant roots which alleviated the levels of LP when exposed to infection. Such results were consistent with Kacharava et al (2009) and Ouhibi et al (2014) who reported that irradiation of kidney bean and lettuce seeds with low doses of UV-C increased the ascorbic acid, tocopherol, phenolic compounds and flavonoids content in plant leaves.

Also, induction of resistance in green bean seedlings grown from GB-treated seeds was associated with reduction in MDA concentration as shown in Fig. (3). These results were supported by Zhang et al (2017) who stated that treatment of apples fruits with GB contributed in lessening the ROS levels and MDA concentration which was associated with higher ability to control blue mold. 


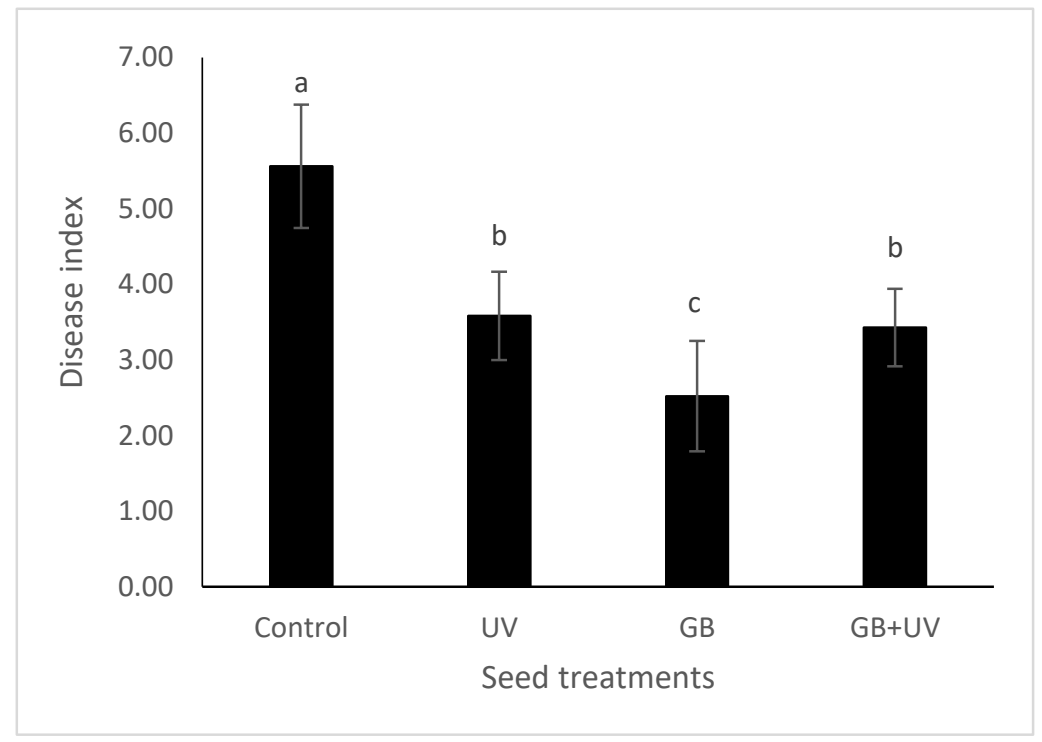

Fig. 1. Effect of pre-sowing seed treatment with UV-C radiation for $60 \mathrm{~min}$ and $\mathrm{GB}(5 \mathrm{mM})$ on disease index in common bean seedlings infected with $R$. solani
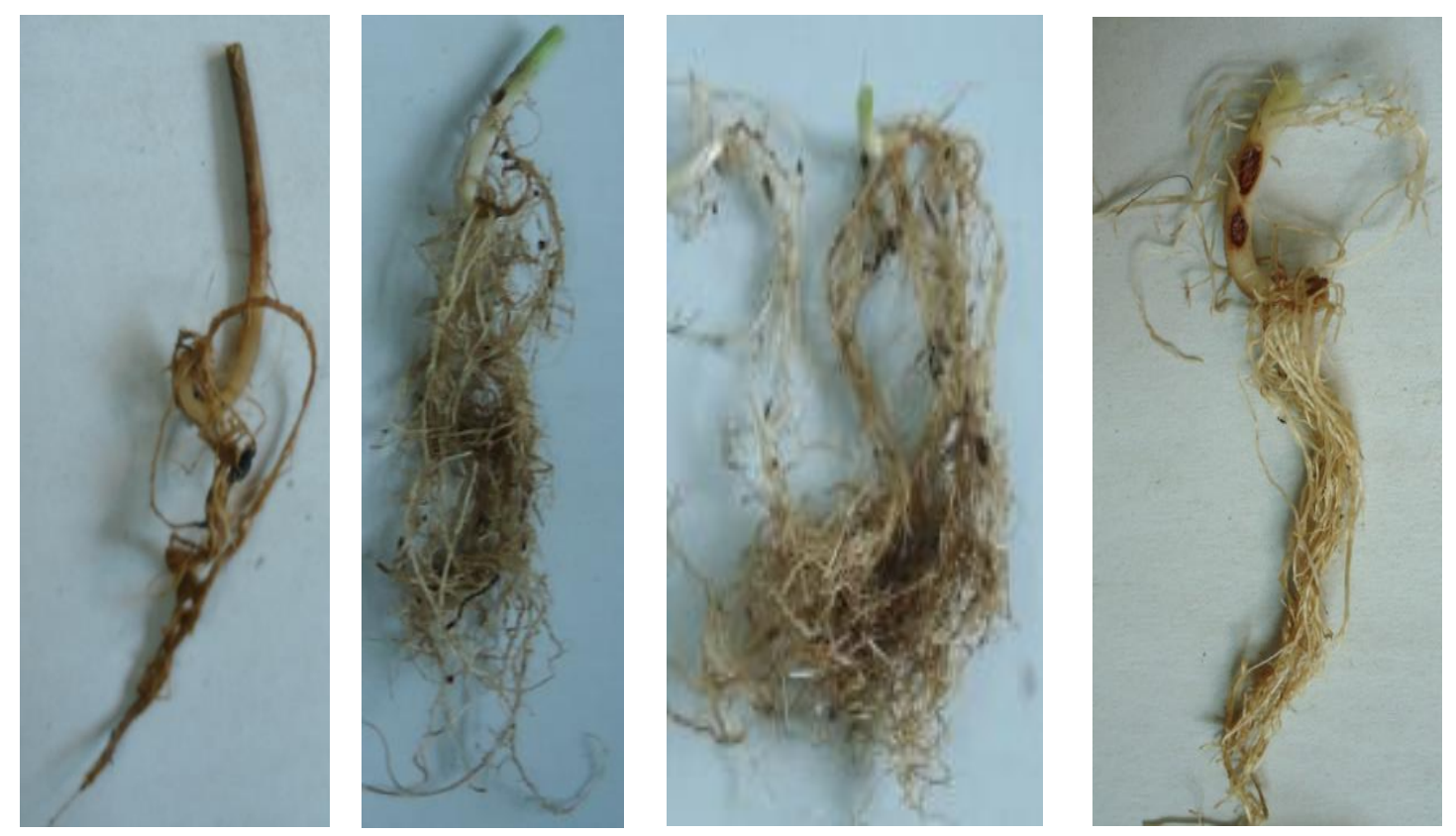

Fig. 2. Effect of pre-sowing seed treatment with (A) water (Control) (B) UV-C (60 min) (C) GB (5 mM) (D) $\mathrm{GB}+\mathrm{UV}$ on disease severity in common bean roots infected with $R$. solani. 


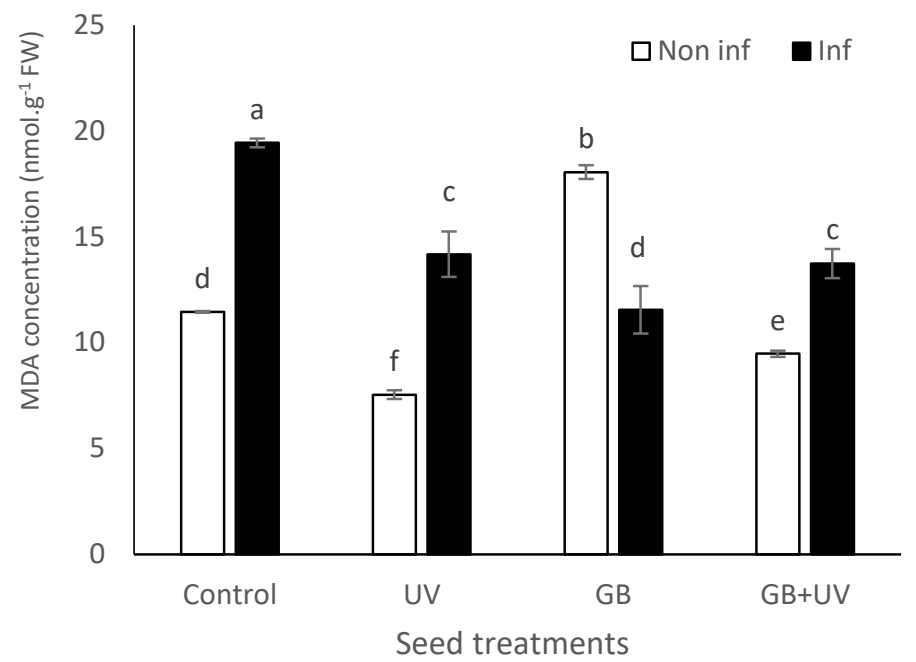

Fig. 3. Effect of seed treatment with UV-C radiation for 60 min and glycine betaine $(5 \mathrm{mM})$ on MDA concentration (nmol. $\mathrm{g}^{-1} \mathrm{FW}$ ) in common bean roots infected or non-infected with $R$. solani.

On the other hand, treatment of green bean seeds with $\mathrm{GB}(5 \mathrm{mM})$ elevated the MDA concentration in non-infected seedlings. This observation was also previously reported in Cicer arietinum L. by Nayyar et al (2005) who elucidated that GB-treated plants showed a three-fold increase in MDA concentration as compared to control and that effect was accompanied by increase in hydrogen peroxide concentration. The promotive effect of GB on MDA concentration can be attributed to the induction of lipoxygenase activity as reported by Karabudak (2014) in tomato and the products of LP may serve as precursors for jasmonic acid synthesis that plays a major signaling role in plant resistance to biotic stress (Browse, 2009). Accordingly, such increase in MDA because of GB treatment in healthy plants originated from sources other than oxidative damage.

\section{Effect of treatments on superoxide dis- mutase activity}

Among all treatments, GB provoked a significant increase $(48.5 \%)$ in SOD activity over the control in non-infected plants as shown in Fig. (4). In contrast, there was no significant difference at $P$ $\leq 0.05$ between UV treatment (61.6 U. $\mathrm{mg}^{-1}$ protein) and control (54.6 U. $\mathrm{mg}^{-1}$ protein). Also, the activity of SOD declined from 54.6 U. $\mathrm{mg}^{-1}$ protein in control non-infected plants to $25 \mathrm{U} . \mathrm{mg}^{-1}$ protein in the combined treatment. Infection with $R$. solani con- siderably elevated the activity of SOD in roots in all treatments. Plants grown from GB-treated seeds showed the highest activity with increment of $36.8 \%$ as compared to infected control. On the other hand, irradiation with UV-C either alone or with GB treatment lowered the activity of SOD as compared to infected control.

Superoxide dismutase is considered as the first-line defense enzyme as it catalyzes the conversion of the superoxide anion radical $\left(\mathrm{O}_{2}^{--}\right)$into the less toxic ROS i.e. hydrogen peroxide $\left(\mathrm{H}_{2} \mathrm{O}_{2}\right)$ which is the substrate for many peroxidases (Alscher et al 2002). Accordingly, it plays a pivotal role in plant resistance to oxidative stress associated with the infection.

In the present study, UV-C had a little effect on elevation of SOD in non-infected seedlings or an inhibitory effect in infected seedlings which can be attributed to the kinetics of formation of superoxide radical after exposure of plant seeds to UV-C, especially if it is known that the half-life of the superoxide anion radical $\left(\mathrm{O}_{2}{ }^{-}\right)$is from 1 to $1000 \mu \mathrm{s}$ (Demidchik, 2015). Also, Kliebenstein et al (1998) declared that gene expression of SOD isozymes in Arabidopsis responded differently to UV$\mathrm{B}$ and their expression levels declined after 2 days from UV-B treatment at maximum. Therefore, the seedling age and the period between the treatment and sampling can be considered as a factor for SOD activity. 


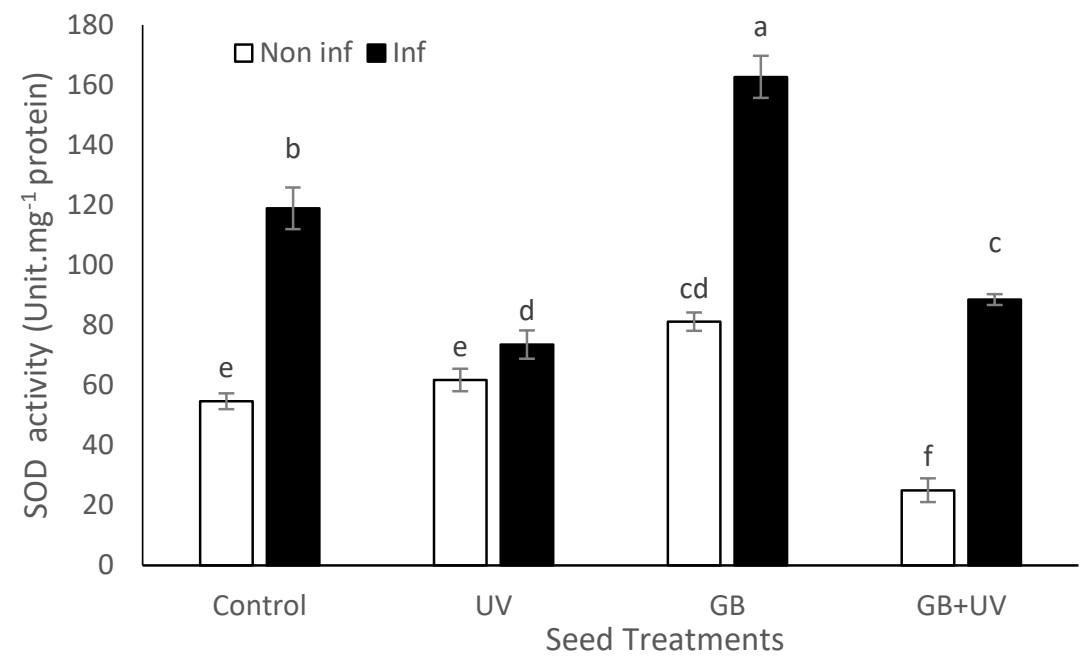

Fig. 4. Effect of seed treatment with UV-C radiation for $60 \mathrm{~min}$ and glycine betaine $(5 \mathrm{mM})$ on SOD activity (Unit.mg-1 protein) in common bean roots infected or non-infected with $R$. solani.

On the other hand, GB exhibited a stimulating effect on SOD in both infected and non-infected seedlings which was also reported by Farooq et al (2008) in hybrid maize. They showed that SOD activity increased in plants because of seed priming with GB which improved tolerance to chilling stress. Glycine betaine may enhance enzyme activity either by increasing the gene expression (Lou et al 2015) or by stabilizing the folded form of the enzyme (Guinn et al 2011).

However, the combination between UV and GB showed an antagonistic effect on SOD which may be attributed to the interference between ROSgenerating effect of UV radiation which act as signaling molecules for activation of ROS-scavenging enzymes (D'Autréaux and Toledano, 2007) and the antioxidant activity of GB. Similar results were obtained by Park et al (2004) who found that GB protected tomato plants from methyl viologeninduced oxidative stress.

\section{Effect of treatments on guaiacol peroxidase activity}

Data in Fig. (5) demonstrate that either UV or GB significantly elevated the activity of G-POD which was not observed in the case of the combined treatment for non-infected plants. The extent of increment was 33.3 and $10.2 \%$ for UV and GB respectively. Infection with $R$. solani stimulated the enzyme activity in all treatments with their respective control in each group. The maximum activity was attained with UV treatment (9042.5 U. $\mathrm{mg}^{-1}$ protein) followed by GB+UV, GB and infected control with values of $7776.5,7152.4$ and 6508.8 U. $\mathrm{mg}^{-1}$ protein respectively.

Guaiacol peroxidase catalyzes the detoxification of $\mathrm{H}_{2} \mathrm{O}_{2}$ in plant cells in the presence of electron donor like guaiacol and has a role in biosynthesis of lignin (Asada, 1999). Therefore, the induction of G-POD in infected seedlings enhanced the plant defense against penetrating fungi as it increases the deposition of lignin in cell wall. It can be concluded that G-POD contributed in disease resistance in seedlings grown from seeds treated with UV and GB individually or in combination. Also, results indicated that G-POD played a role in lowering the lipid peroxidation which was reflected by the lower numbers of necrosis lesions in the case of GB, UV and GB+UV treatments.

\section{6- Effect of treatments on polyphenol oxidase activity}

Data in Fig. (6) illustrate that the activity of PPO was remarkably upregulated by all treatments in non-infected plants. The PPO activity exhibited similar behavior with UV (344.6 U. $\mathrm{mg}^{-1}$ protein), GB (338.6 U. $\mathrm{mg}^{-1}$ protein) and combined treatment (350.9 U. $\mathrm{mg}^{-1}$ ) as there were no significant 


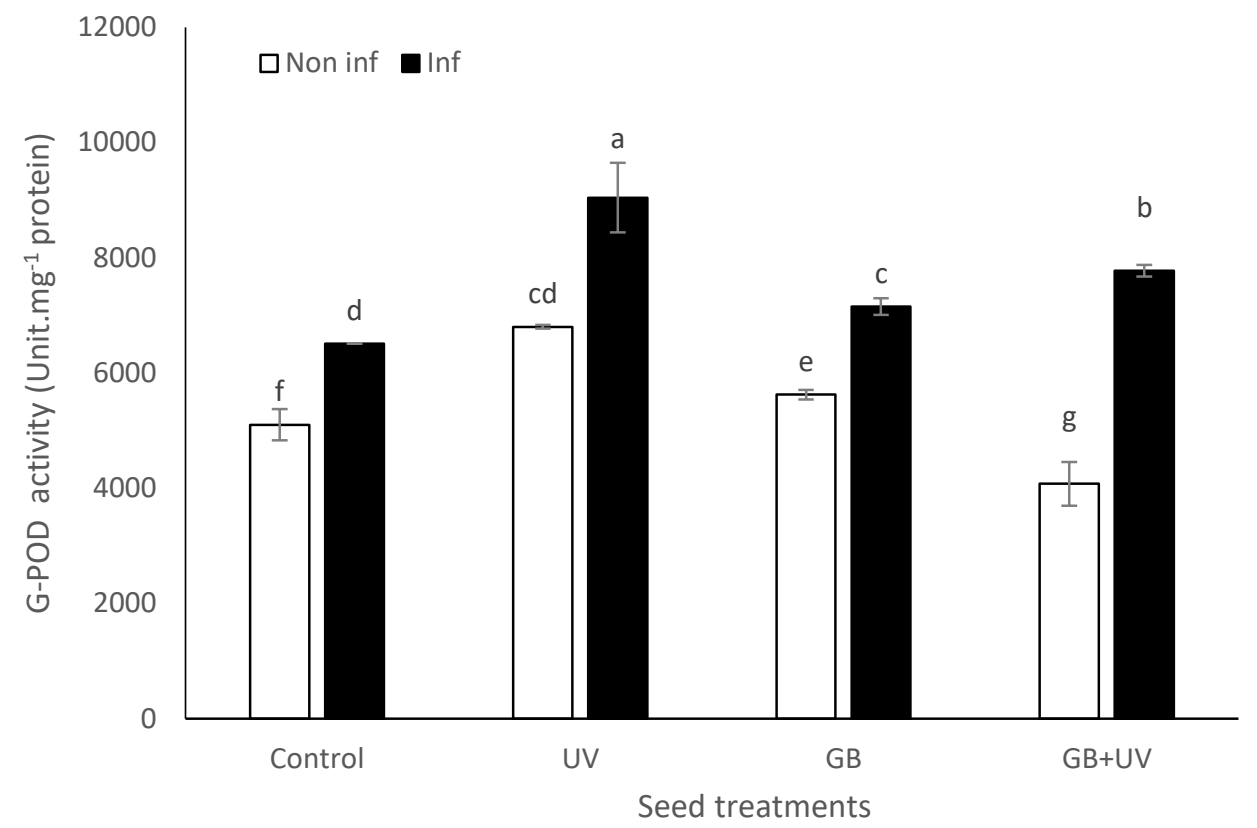

Fig. 5. Effect of seed treatment with UV-C radiation for 60 min and glycine betaine $(5 \mathrm{mM})$ on G-POD activity (Unit. $\mathrm{mg}^{-1}$ protein) in common bean roots infected or non-infected with $R$. solani.

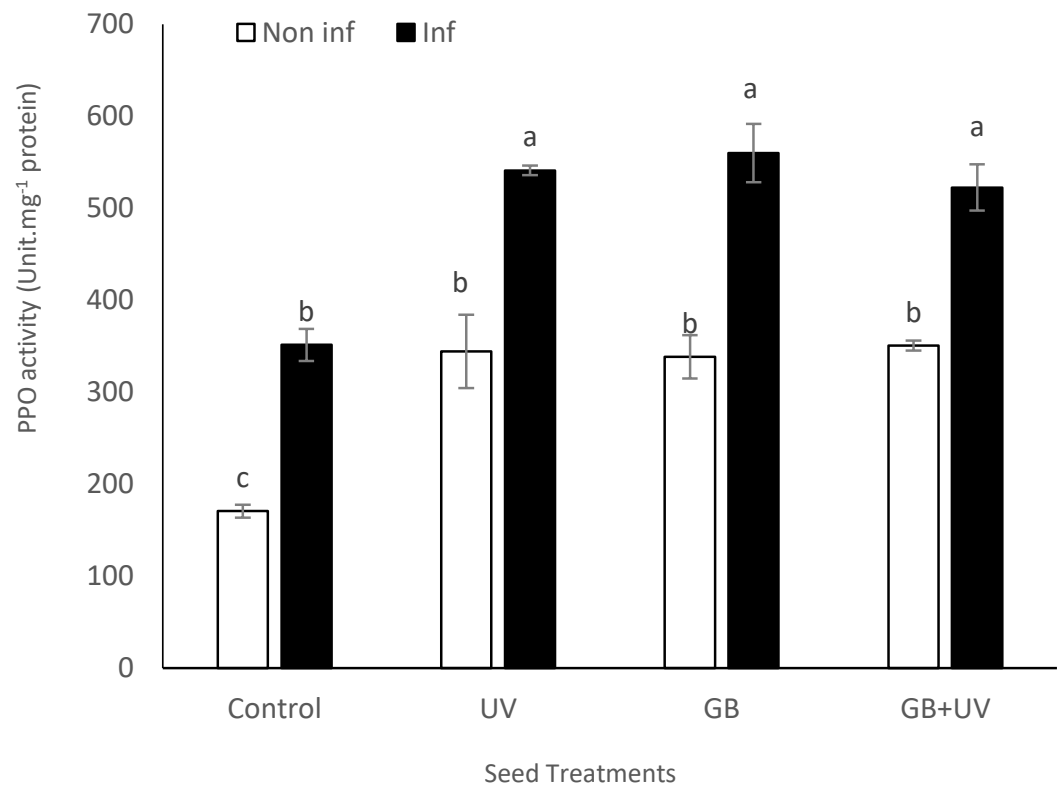

Fig. 6. Effect of seed treatment with UV-C radiation for $60 \mathrm{~min}$ and glycine betaine $(5 \mathrm{mM})$ on PPO activity (Unit. $\mathrm{mg}^{-1}$ protein) in common bean roots infected or non-infected with $R$. solani 
variations between them at $P \leq 0.05$. Similarly, the activity of PPO was increased by infection in all treatments. Nevertheless, the activity of PPO showed higher response in all treatments compared with control. All treatments led to significant increases over the infected control with percentages of $54,59.4$ and $48.7 \%$ for UV, GB and $\mathrm{UV}+\mathrm{GB}$, respectively.

Polyphenol oxidase (PPO) is a coppercontaining enzyme which catalyzes oxidation of ortho-diphenols like catechol to their respective quinones (antimicrobial compounds) using molecular oxygen (Constabel and Barbehenn, 2008). Induction of PPO by UV in the present study confirms the finding of Mahdavian et al (2008). They declared that salicylic acid signaling pathway had a role in this process.

By contrast, the results of PPO in the GB treatment are opposed to results of Wang et al (2015) who reported that GB as a post-harvest treatment directly inhibited the PPO by its reaction with the copper ions in the active center. Therefore, the effect of GB on PPO activity needs to be elucidated by further investigations. Nevertheless, it can be concluded that PPO implicated in resistance to $R$. solani in common bean seedlings.

The observations in this report supported the hypothesis of Luckey (1980) who proposed that radiation hormesis should cause repairable damage of DNA which activate the repair mechanisms such as excision repair (dark activation) and post replication repair. Such effect may stimulate vital processes inside the cells like overcompensation of normal metabolic processes, stimulation of the basic physiological functions that had previously been repressed and directing the homeostasis of the plant to a positive change.

Another explanation for the effect of UV depends on the role of ROS as signaling molecules. Zacchini and de Agazio (2004) found that $\mathrm{H}_{2} \mathrm{O}_{2}$ served as a signaling molecule transmitted from cell layers exposed to UV to the whole callus of tobacco and the effect of UV was extended to cell layers which were not exposed to UV.

Generally, it can be concluded that seed priming with UV-C or GB enhanced common bean resistance to $R$. solani by activation of the antioxidant system and there was no synergistic effect between UV and GB. The maximum reduction in the disease index was observed in seedlings grown from GB-treated seeds, so it is expected that $G B$ enhanced plant defense by more than one mechanism which needs more investigations at the level of resistance genes expression.

\section{REFERENCES}

Abawi G.S., Ludwig J.W. and Gugino B.K. 2006. Bean root rot evaluation protocols currently used in New York. Annual. Rep. Bean Improv. Coop. 49, 83-84.

Abdel-Fattah G.M., El-Haddad S.A., Hafez E.E. and Rashad Y.M. 2011. Induction of defense responses in common bean plants by arbuscular mycorrhizal fungi. Microbiological Research 166(4), 268-281.

Doi:10.1016/j.micres.2010.04.004.

Aboul Fotouh M.M., Moawad F.G., El-Naggar H.A., Tag El-Din M.A. and Sharaf Eldeen H.A. 2014. Influence of seed treatment with UV-C on saline stress tolerance in green beans (Phaseolus vulgaris L.). J. of Biol. Chem. 9(2), 391-414.

Alscher R.G., Erturk N. and Heath L.S. 2002. Role of superoxide dismutases (SODs) in controlling oxidative stress in plants. Journal of Experimental Botany 53(372), 1331-1341.

Doi: 10.1093/jexbot/53.372.1331.

Arcury T.A. and Quandt S.A. 2003. Pesticides at work and at home: exposure of migrant farmworkers. The Lancet 362 (9400), 2021. Doi: 10.1016/S0140-6736(03)15027-1.

Asada K. 1999. The water-water cycle in chloroplasts: scavenging of active oxygens and dissipation of excess photons. Annu. Rev. Plant Physiol. Plant Mol. Biol. 50(1), 601-639.

Doi: 10.1146/annurev.arplant.50.1.601.

Basra S.M.A., Farooq M., Rehman H. and Saleem B.A. 2007. Improving the germination and early seedling growth in melon (Cucumis melo L.) by pre-sowing salicylicate treatments. Int. J. of Agric. and Biology 9(4), 550-554.

Beyer W.F. and Fridovich I. 1987. Assaying for superoxide dismutase activity: some large consequences of minor changes in condition. Anal. Biochem. 161(2), 559-566.

Doi: 10.1016/0003-2697(87)90489-1

Bradford M.M. 1976. A rapid and sensitive method for the quantification of microgram quantities of protein utilizing the principles of protein-dye binding. Anal. Biochem. 72, 243-254.

Doi: 10.1016/0003-2697(76)90527-3 
Brown J.E., Lu T.Y., Stevens C., Khan V.A., Lu J.Y., Wilson C.L., Collins D.J., Wilson M.A., Igwegbe E.C.K., Chalutz E. and Droby S. 2001. The effect of low dose ultraviolet light-C seed treatment on induced resistance in cabbage to black rot (Xanthomonas campestris $p v$. campestris). Crop Prot. 20(10), 873-883.

Doi: 10.1016/S0261-2194(01)00037-0.

Browse J. 2009. Jasmonate passes muster: a receptor and targets for the defense hormone. The Annual Review of Plant Biology 60(1), 183-205.

Doi: 10.1146/annurev.arplant.043008.092007.

Conrath U. 2011. Molecular aspects of defence priming. Trends in Plant Sci. 16(10), 524-531.

Doi: 10.1016/j.tplants.2011.06.004

Constabel C.P. and Barbehenn R. 2008. Defensive roles of polyphenol oxidase in plants. In: Schaller A. (eds) Induced plant resistance to herbivory. pp. 253-270. Springer, Dordrecht, Netherlands. Doi: 10.1007/978-1-4020-81828_12.

D'Autréaux B. and Toledano M.B. 2007. ROS as signalling molecules: mechanisms that generate specificity in ROS homeostasis. Nature Reviews: Molecular Cell Biology 8(10), 813-824. Doi:10.1038/nrm2256.

De La Fuente M., Borrajo A., Bermúdez J., Lores M., Alonso J., López M., Santalla M., De Ron A.M., Zapata C. and Alvarez G. 2011. 2-DE-based proteomic analysis of common bean (Phaseolus vulgaris L.) seeds. J. Proteomics 74(2), 262-267. Doi: 10.1016/j.jprot.2010.10.004.

Demidchik V. 2015. Mechanisms of oxidative stress in plants: From classical chemistry to cell biology. Environmental and Experimental Botany 109, 212-228.

Doi: 10.1016/j.envexpbot.2014.06.021.

Dixon R.A. 2001. Natural products and plant disease resistance. Nature 411(6839), 843-847. DOI: $10.1038 / 35081178$.

El-Mougy N.S., El-Gamal N.G.E. and AbdelKader M.M. 2007. Control of wilt and root rot incidence in Phaseolus vulgaris L. by some plant volatile compounds. J. Plant Protect. Res. 47(3), 255-265.

Fakir G.A. 1983. Teaching, research and training activities on seed pathology in Bangladesh. Seed Sci. Technol. 11, 1345-1352.

Farmer, E.E. and Mueller M.J. 2013. ROSMediated Lipid Peroxidation and RES-Activated Signaling. Annual Review of Plant Biology $64(1)$, 429-450.
Doi: 10.1146/annurev-arplant-050312-120132.

Farooq M., Aziz T., Hussain M., Rehman H., Jabran K. and Khan M.B. 2008. Glycine betaine improves chilling tolerance in hybrid maize. J. of Agronomy \& Crop Sci. 194(2), 152-160. Doi: 10.1111/j.1439-037X.2008.00295.x.

Guerrero-González M.L., Rodríguez-Kessler M., Rodríguez-Guerra R., González-Chavira M., Simpson J., Sanchez F. and JiménezBremont J.F. 2011. Differential expression of Phaseolus vulgaris genes induced during the interaction with Rhizoctonia solani. Plant Cell Rep. 30(8), 1465- 1473. Doi: 10.1007/s00299011-1055-5.

Guinn E.J., Pegram L.M., Capp M.W., Pollock M.N. and Record Jr M.T. 2011. Quantifying why urea is a protein denaturant, whereas glycine betaine is a protein stabilizer. PNAS 108(41), 16932-16937. Doi: 10.1073/pnas.1109372108.

Hajieghrari B., Torabi-Giglou M., Mohammadi M.R. and Davari M. 2008. Biological potantial of some Iranian Trichoderma isolates in the control of soil borne plant pathogenic fungi. African $\mathrm{J}$. of Biotechnology 7(8), 967-972.

Hammerschmidt R., Nuckles E.M. and Kuć J. 1982. Association of enhanced peroxidase activity with induced systemic resistance of cucumber to Colletotrichum lagenarium. Physiol. Plant Pathol. 20(1), 73-82. Doi: 10.1016/00484059(82)90025-X.

Heath R.L. and Packer L. 1968. Photoperoxidation in isolated chloroplasts. 1. Kinetics and stoichiometry of fatty acids peroxidation. Arch. Biochem. Biophys. 125(1), 189-198. Doi: 10.1016/0003-9861(68)90654-1.

Kacharava N., Chanishvili S., Badridze G., Chkhubianishvili E. and Janukashvili $N$. 2009. Effect of seed irradiation on the content of antioxidants in leaves of kidney bean, cabbage and beet cultivars. Australian J. of Crop Sci. 3(3), 137-145.

Karabudak T., Bor M., Özdemir F. and Türkan I. 2014. Glycine betaine protects tomato (Solanum lycopersicum) plants at low temperature by inducing fatty acid desaturase7 and lipoxygenase gene expression. Molecular biology reports 41(3), 1401-1410. Doi: 10.1007/s11033-0132984-6.

Kaur S., Gupta A.K. and Kaur N. 2002. Effect of osmo- and hydropriming of chickpea seeds on seedling growth and carbohydrate metabolism under water deficit stress. Plant Growth Regulation 37(1), 17-22. 
Doi: 10.1023/A:1020310008830.

Kliebenstein D.J., Monde R. and Last R.L. 1998. Superoxide dismutase in Arabidopsis: An eclectic enzyme family with disparate regulation and protein localization. Plant Physiology 118(2), 637-650. Doi: 10.1104/pp.118.2.637.

Lavanya N.S. and Amruthesh N.K. 2017. Glycine betaine mediated disease resistance against Sclerospora graminicola in pearl millet. J. of Applied Biol. \& Biotechnol. 5(3), 45-51.

Doi: 10.7324/JABB.2017.50308.

Lou Y., Yang Y., Hu L., Liu H. and Xu Q. 2015. Exogenous glycinebetaine alleviates the detrimental effect of $\mathrm{Cd}$ stress on perennial ryegrass. Ecotoxicology 24(6), 1330-1340.

Doi: 10.1007/s1064.

Luckey T.D. 1980. Hormesis with lonizing Radiation. CRC Press Inc., Boca Raton, Florida.

Mahdavian K., Ghorbanli M. and Kalantari K.M. 2008. The Effects of ultraviolet radiation on the contents of chlorophyll, flavonoid, anthocyanin and proline in Capsicum annuum L. Turk J. Bot. 32(1), 25-33.

Mayo S., Gutiérrez S., Malmierca M.G., Lorenzana A., Campelo M.P., Hermosa R. and Casquero P.A. 2015. Influence of Rhizoctonia solani and Trichoderma spp. in growth of bean (Phaseolus vulgaris L.) and in the induction of plant defense-related genes. Front. Plant Sci. 6, 685. Doi: 10.3389/fpls.2015.00685

Maha H. Mohamed, Gado E., El-Deeb S. and Mostafa M.H. 2015a. Phenotypic diversity and molecular identification of the most prevalent anastomosis group of Rhizoctonia solani isolated from diseased faba bean plants. American J. of Life Sci. 3(1), 47-55.

Doi: 10.11648/j.ajls.20150301.19.

Maha H. Mohamed, Gado E., El-Deeb S. and Mostafa M.H. 2015b. Obstruction of signal transduction between faba bean and Rhizoctonia solani during pathogenesis and its impact on root rot disease. Int. Scientific Research J. 1(7), 99-106. Doi: 10.18483/IRJSci.50.

Nayyar H., Chander K., Kumar S. and Bains T. 2005. Glycine betaine mitigates cold stress damage in Chickpea. Agronomy for Sustainable Development, Springer Verlag/EDP Sciences/INRA 25(3), 381-388. DOI: 10.1051/agro:2005033

Oktay M., Küfrevioğlu I., Kocacalışkan I. and Sakiroğlu H. 1995. Polyphenol oxidase from Amasya apple. J. Food Sci. 60(3), 494-496. Doi: 10.1111/j.1365-2621.1995.tb09810.x.
Ouhibi C., Attia H., Rebah F., Msilini N., Chebbi M., Aarrouf J., Urban L. and Lachaal M. 2014. Salt stress mitigation by seed priming with UV-C in lettuce plants: Growth, antioxidant activity and phenolic compounds. Plant Physiology and Biochemistry 83, 126-133.

Doi: 10.1016/j.plaphy.2014.07.019

Park E., Jeknić Z., Sakamoto A., DeNoma J., Yuwansiri R., Murata N. and Chen T.H.H. 2004. Genetic engineering of glycine betaine synthesis in tomato protects seeds, plants, and flowers from chilling damage. The Plant J. 40(4), 474-487.

Doi: 10.1111/j.1365-313X.2004.02237.x.

Paul S. and Roychoudhury A. 2017. Seed priming with spermine and spermidine regulates the expression of diverse groups of abiotic stress-responsive genes during salinity stress in the seedlings of indica rice varieties. Plant Gene. 11(B), 124-132.

Doi: 10.1016/j.plgene.2017.04.004.

Rady M.M., Varma B.C. and Howladar S.M. 2013. Common bean (Phaseolus vulgaris L.) seedlings overcome $\mathrm{NaCl}$ stress as a result of presoaking in Moringa oleifera leaf extract. Scientia Horticulturae 162, 63-70.

Doi: 10.1016/j.scienta.2013.07.046.

Sahar A. Youssef, Tartoura K.A. and Ghada A. Abdelraouf 2016. Evaluation of Trichoderma harzianum and Serratia proteamaculans effect on disease suppression, stimulation of ROSscavenging enzymes and improving tomato growth infected by Rhizoctonia solani. Biological Control 100, 79-86. Doi: 10.1016/j.biocontrol.2016.06.001.

Scott G., Almasrahi A., Mansoorkhani F.M., Rupar M., Dickinson M. and Shama G. 2019. Hormetic UV-C seed treatments for the control of tomato diseases. Plant Pathol. 68(4), 700707. Doi:10.1111/ppa.12987

Shams M., Yildrim E., Ekinci M., Turan M., Dursun A., Parlakova F. and Kul R. 2016. Exogenously applied glycine betaine regulates some chemical characteristics and antioxidative defence systems in lettuce under salt stress. Hortic. Environ. Biotechnol. 57(3), 225-231. Doi: 10.1007/s13580-016-0021-0.

Sivalingam P.N., Vishwakarma S.N. and Singh U.S. 2006. Role of seed-borne inoculum of Rhizoctonia solani in sheath blight of rice. Indian Phytopath. 59(4), 445-452

Srivastava R., Khalid A., Singh U.S. and Sharma A.K. 2010. Evaluation of arbuscular mycorrhizal fungus, fluorescent Pseudomonas and 
Trichoderma harzianum formulation against Fusarium oxysporum f. sp. lycopersici for the management of tomato wilt. Biological Control 53(1), 24-31.

Doi: 10.1016/j.biocontrol.2009.11.012.

Stern R. 1991. CoStat-Statistical Software. California: CoHort Software (1989). Experimental Agric. 27(1), $87 \mathrm{p}$.

Wang H., Chen Z., Liu G., Bai C., Qiu H., Jia Y. and Luo L. 2017. Alterations of growth, antioxidant system and gene expression in Stylosanthes guianensis during Colletotrichum gloeosporioides infection. Plant Physiology and Biochemistry 118, 256-266.

Doi: 10.1016/j.plaphy.2017.06.024.

Wang Z., Chen L., Yang H. and Wang A. 2015. Effect of exogenous glycine betaine on qualities of button mushrooms (Agaricus bisporus) during postharvest storage. Eur. Food Res. Technol. 240(1), 41-48. Doi: 10.1007/s00217-014-2305$x$.
Xu Y., Charles M.T., Luo Z., Mimee B., Tong Z., Véronneau P., Roussel D. and Rolland $D$. 2019. Ultraviolet-C priming of strawberry leaves against subsequent Mycosphaerella fragariae infection involves the action of reactive oxygen species, plant hormones, and terpenes. Plant Cell and Environment 42(3), 815-831.

Doi: 10.1111/pce.13491.

Zacchini M. and de Agazio M. 2004. Spread of oxidative damage and antioxidative response through cell layers of tobacco callus after UV-C treatment. Plant Physiol. Biochem. 42(5), 445450. Doi: 10.1016/j.plaphy.2004.03.007.

Zhang X., Zhang G., Li P., Yang Q., Chen K., Zhao L., Apaliya M.T., Gu X. and Zhang $H$. 2017. Mechanisms of glycine betaine enhancing oxidative stress tolerance and biocontrol efficacy of Pichia caribbica against blue mold on apples. Biological Control 108, 55-63. Doi: 10.1016/j.biocontrol.2017.02.011. 


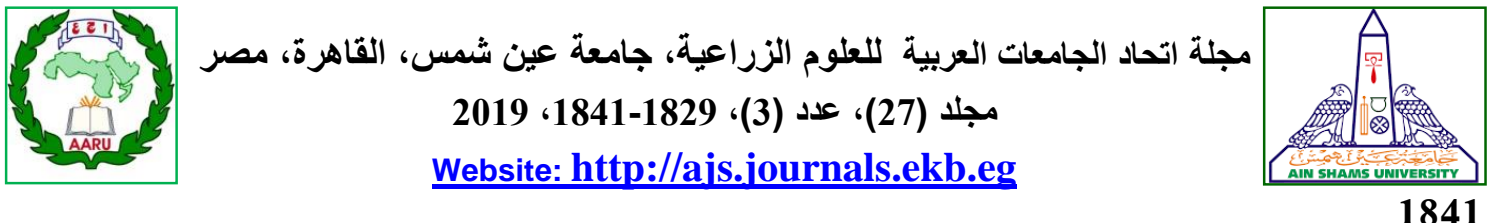

تحسين المقاومة ضد Rhizoctonia solani بواسطة الجليسين بيتايين والأثثعة فوق البنفجية (UV-C) في الفاصوليا الخضراء

[146]

محمد محمود أبوالفتوح1" - مها حلمي محمد2 - فاروق جندي معوض1 1 - ممدوح أبو مسلم تاج الدين 1 هاني عبد الله محمد سرور 1

1- قسم الكيمياء الحيوية الزراعية - كلية الزراعة - جامعة عين شمس - ص.ب 68 - حدائق شبرا 11241 - القاهرة -

$$
\text { 2- قصم أمراض النبات - كلية الزراعة - جامعة عين شمس - ص.ب 68- حدائق شبرا } 11241 \text { - القاهرة - مصر }
$$

*Corresponding author: mohamed mesalhi@agr.asu.edu.eg

Received 24 July, 2019 Accepted 18 September, 2019

على أكسدة اللبيدات (مستويات المـالون داي ألدهيد)

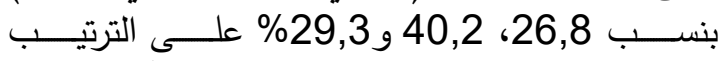
بالمقارنـة بالمجموعة الضـابطة المصـابة. أمسا بالنسبة

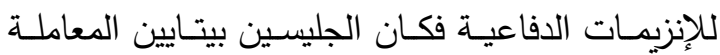

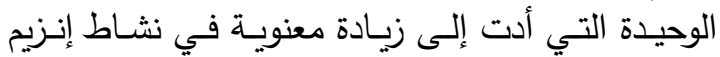

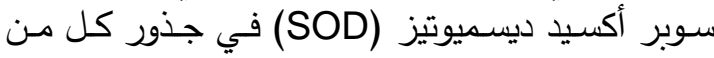

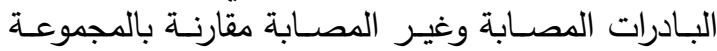

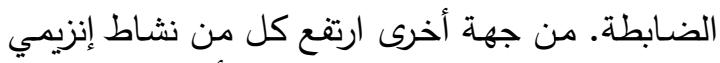

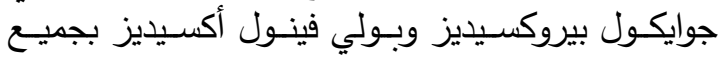

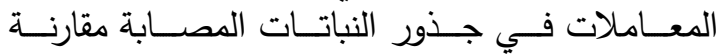

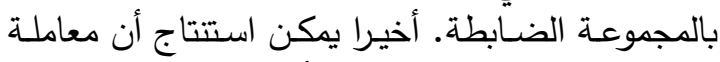

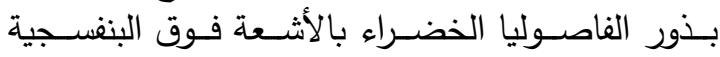

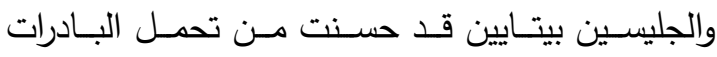

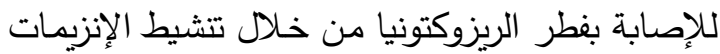

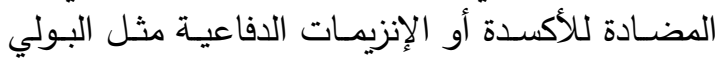

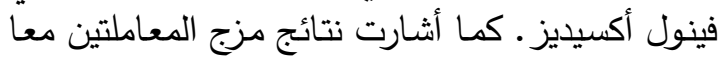

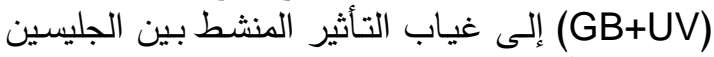

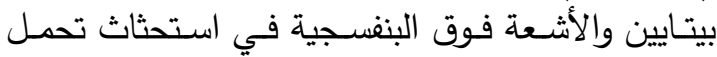

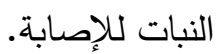

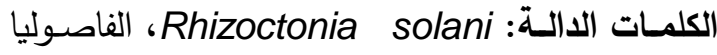

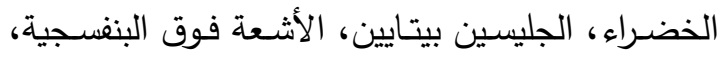
معاملة البذور ، المقاومة المستحثة لائن

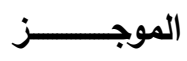

يعتبر فطر الريزوكتونيا واحدا من أهم المسببات

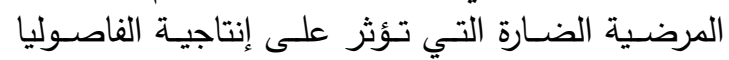

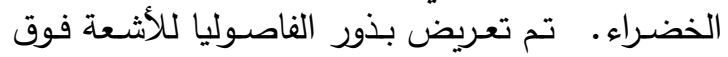

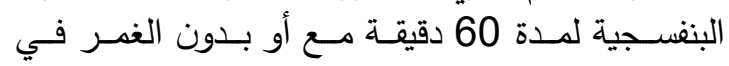

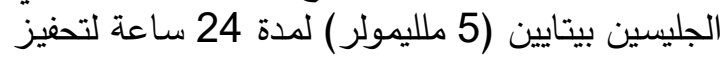

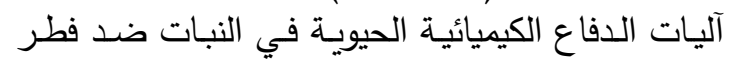

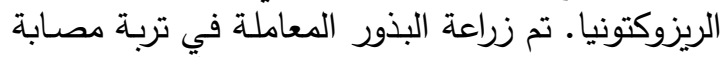

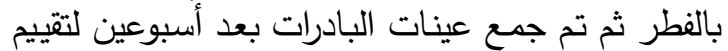

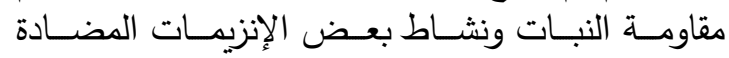

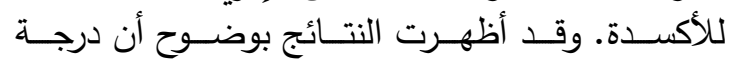

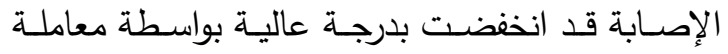
الجليسين بيتايين بنسبة 54,7 \% ويتبع ذلك الكباتين المعاملة

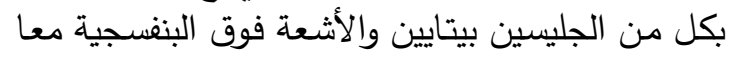

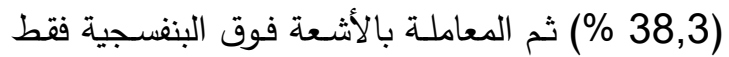

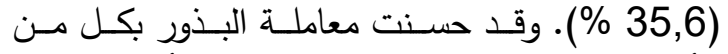

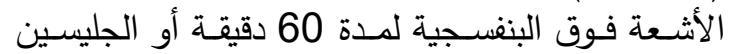

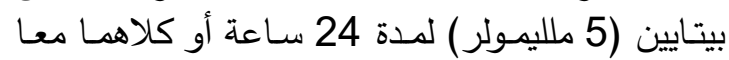

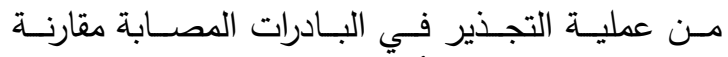

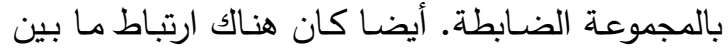

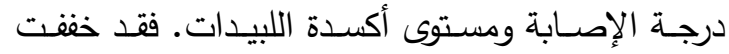

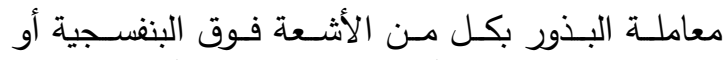

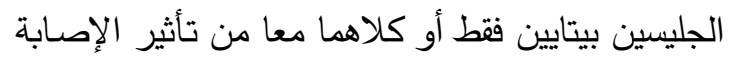

$$
\text { تحكيم: ا.د عماد صبري شاكر }
$$

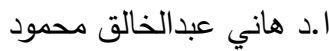


أبوالفتوح - مها محم - معوض - تاج الدين - سرور 